удк 657.37:005.53

\title{
ВНУТРІШНЬОГОСПОДАРСЬКА ЗВІТНІСТЬ ЯК ІНСТРУМЕНТ ДЛЯ ПРИЙНЯТТЯ УПРАВЛІНСЬКИХ РІШЕНЬ
}

\section{INTERNAL BUSINESS REPORTING AS A TOOL FOR MAKING MANAGEMENT DECISIONS}

\author{
Штуфт Поліна Вікторівна \\ аспірант, \\ Одеський національний економічний університет \\ ORCID: https://orcid.org/0000-0003-0400-3711 \\ Артюх Оксана Валентинівна \\ доктор економічних наук, доцент, профресор, \\ Одеський національний економічний університет \\ ORCID: https://orcid.org/0000-0002-8845-8002
}

\author{
Shtuft Polina, Artukh Oksana \\ Odessa National Economic University
}

\begin{abstract}
Стаття присвячена актуальним питанням визначення сутності внутрішньогосподарської звітності, а також визначення її ролі в системі управління підприємствами. Розглянуті поняття «внутрішня звітність» та «управлінська звітність», а також їх трактування у роботах вітчизняних науковців та практиків. Розглянуті вимоги щодо формування управлінської звітності, які можуть розкрити повний стан роботи підприємства та надати повну та достовірну інформацію для керівників стосовно подальшого прийняття управлінських рішень. Виявлено, що внутрішньогосподарська звітність є одним з основних джерел інформації про діяльність підприємства, а також важливим інструментом контролю за господарською діяльністю. Зазначено, що така звітність повинна бути оперативною, короткою та подаватися тоді, коли вона необхідна для прийняття конкретних управлінських рішень без зайвої інформації.
\end{abstract}

Ключові слова: внутрішня звітність, внутрішньогосподарська звітність, управлінська звітність, оперативна звітність, внутрішньо-корпоративна управлінська звітність, управлінські рішення.

Статья посвящена актуальным вопросам определения сущности внутрихозяйственной отчетности, а также определение ее роли в системе управления предприятиями. Рассмотрены понятия «внутренняя отчетность» и «управленческая отчетность», а также их трактовка в работах отечественных ученых и практиков. Рассмотрены требования по формированию управленческой отчетности, которые могут раскрыть полное состояние работы предприятия и предоставить полную и достоверную инфрормацию для руководителей относительно дальнейшего принятия управленческих решений. Выявлено, что внутрихозяйственная отчетность является одним из основных источников информации о деятельности предприятия, а также важным инструментом контроля за хозяйственной деятельностью. Указано, что такая отчетность должна быть оперативной и подаваться тогда, когда она необходима для принятия конкретных управленческих решений без лишней информации.

Ключевые слова: внутренняя отчетность, внутрихозяйственная отчетность, управленческая отчетность, оперативная отчетность, внутренне корпоративная управленческая отчетность, управленческие решения.

The article is devoted to topical issues of determining the essence of internal reporting, as well as defining its role in the enterprise management system. The concepts of «internal reporting» and «management reporting», as well as their interpretation in the works of domestic scholars and practitioners are considered. Analyzed the term «internal reporting» by Ukrainian scientists, and provided their own interpretation of this term the requirements for the formation of management reporting are considered, which can reveal the full state of the enterprise and provide complete and reliable information for managers regarding further management decisions. It is also noted that for corporate enterprises the concepts of «internal reporting» and «management reporting» are not informative enough, so it is advisable to use the term «internal corporate management reporting», as such a term discloses information about the purpose of further use of information contained in these reports, as well as the subjects whose interests 
it affects. Also there was found that internal business reporting is one of the main sources of information about the activities of the enterprise, as well as an important tool for monitoring business activities. Considering management reporting as a source of information about the state of the enterprise, three groups of information are distinguished by which managers of various levels of management are guided: strategic information, tactical information, operational information. It is stated that such reporting should be prompt, concise and submitted when it is necessary to make specific management decisions without unnecessary information. Given the requirements for the formation of management reporting, such reporting must be reliable, objective and understandable, so that each individual responsible manager can receive the information in which he is interested. Studies have also shown that in most cases, companies do not have general rules for the formation of such reports, as well as insufficient qualifications of employees, which in turn is accompanied by a lack of legislative regulation of management accounting.

Keywords: internal reporting, internal business reporting, management reporting, operational reporting, internal corporate management reporting, management decisions.

Постановка проблеми. На сьогодні проблемним питанням є формування такої звітності для підприємства, яка б могла задовольнити потреби щодо прийняття оптимальних управлінських рішень. Ця звітність становить комерційну таємницю підприємства і не підлягає оприлюдненню, оскільки її вид, зміст, форми і терміни подання встановлюються внутрішніми розпорядчими документами конкретного суб'єкта господарювання залежно від специфіки діяльності, індивідуальних потреб і вимог внутрішніх користувачів. Така звітність у сучасних умовах фрункціонування господарюючих суб'єктів посилює завдання, зумовлене необхідністю забезпечення стратегії стабільного розвитку, зростання вартості підприємства та забезпечення безперервної діяльності. Для стабільної роботи підприємства на ринку необхідно правильно та раціонально управляти виробництвом, грошовими потоками та інвестиціями.

Аналіз останніх досліджень і публікацій. Дослідження проблем інорормаційності внутрішньогосподарської звітності, доцільності її використання управлінською ланкою розкривалися у роботах вітчизняних практиків та науковців, таких як: Валуєв Б., Бакаєв А., Бутинець Ф., Голов С., Данкевич А., Колісник М., Ластовецький В., Нападовська Л., Прохорова Л., Палій В., Пушкар М. тощо. Втім і досі залишаються відкритими питання концептуального характеру внутрішньогосподарської звітності, їі ролі у системі управління суб'єктів господарювання, що і обумовило напрям наукового пошуку.

Виділення невирішених раніше частин загальної проблеми. В ході проведення наукових досліджень, виявлено, що відсутня законодавча регламентація управлінського обліку, що спричиняє низку невирішених питань стосовно порядку фрормування та подання внутрішньогосподарської звітності.

Формулювання цілей статті (постановка завдання). Метою даної роботи є розкриття сутності внутрішньогосподарської звітності та визначення їі ролі у системі управління суб'єкта господарювання.

Виклад основного матеріалу дослідження. Ефрективне управління підприємством значною мірою залежить від достовірності, повноти, доречності та своєчасності інформації стосовно характеру та обсягу здійснюваних господарських процесів, наявність та використання матеріальних, трудових і фрінансових ресурсів, джерел отримання фрінансових результатів діяльності та напрямів використання прибутку. Найважливішим джерелом такого інфрормаційного забезпечення $€$ звітність, яка готується шляхом виконання спеціальних процедур обробки, групування і підрахунку даних і формується на завершальній стадії облікового процесу.

Поняття «внутрішня звітність» полягає в можливості представлення інорормації про діяльність підприємства не лише за допомогою економічних, а й технологічних показників. Зокрема Бакаєв А. зазначає, що внутрішня звітність - це використовувана для потреб управління система збору інформації в грошовому і натуральному вимірі про фракти господарської діяльності, які впливають не тільки на фрінансові, а й на виробничі й технологічні показники організації [3, с. 104].

У своїх роботах Палій В. пов'язує внутрішню звітність із потребами управлінського персоналу підприємства та вказує, що внутрішня звітність - це сукупність упорядкованих показників та іншої інформації про діяльність підприємства. У ній подається інтерпретація відхилень від цілей, планів і кошторисів, без чого управлінський облік залишається фрормальним скупченням цифрових даних, не придатних для цілей внутрішнього управління $[17$, с. 211].

Внутрішня звітність повинна забезпечити швидке визначення фактичних показників і результатів, їх відхилень від планів та кошторисів, оцінку недоліків і вибір варіантів їх усу- 
нення. Також, внутрішня звітність може бути різною за частотою подання (річною, квартальною, місячною, щотижневою, щоденною, чи може подаватися тільки у випадках якихось відхилень).

Ластовецький В.О. виділяв пріоритетність первинної (вхідної) інформації та зазначав, що «первинні узагальнення - це складова частина первинного обліку, вони є об'єктивно обов'язковими для всіх видів діяльності. А також у звітах матеріально відповідальних осіб $є$ водночас і складовою частиною, першою стадією внутрішньогосподарської звітності» $[14$, с. 33]. Для створення раціональної системи внутрішньогосподарської звітності автор вважав за необхідне спочатку визначитися 3 вхідними інфрормаційними потоками та фрормою і змістом звітів.

Основними користувачами внутрішньогосподарської звітності за центрами відповідальності $€$ менеджери всіх рівнів управління і персонал (адміністрація) підприємства. Ведення обліку і складання звітності за центрами відповідальності підвищує дисципліну і відповідальність менеджерів.

Якщо розглядати первинну реєстрацію господарських операцій за допомогою документів та наступне їх групування на рахунках - це дає можливість оперативно контролювати хід господарської діяльності на окремих ділянках роботи підприємства, а звітність в свою чергу, містить інформацію за підсумками та результатами роботи підприємства в цілому, а також за його окремими ділянками, галузями за відповідні звітні періоди. Відштовхуючись від цього слід зазначити, що внутрішня звітність повинна охопити великий обсяг інфрормації в своєму звіті, але це повинно бути легко доступним для її розуміння та планування майбутньої діяльності підприємства.

Досліджуючи роботи наукових вчених та фрахівців видно, що єдиного ставлення до поняття внутрішньої звітності немає (табл. 1).

Отже, існує велике розмаїття поглядів щодо тлумачення внутрішньогосподарської звітності, де автори виділили свої погляди стосовно управлінської та внутрішньої звітності:

- управлінська звітність складається за центрами відповідальності і загалом по підприємству та подається управлінському персоналу різних рівнів;

- управлінська звітність повинна відображати умови, специфіку, особливості діяльності підприємства та потреби управлінського персоналу;
- управлінська звітність являє собою доволі гнучку систему фрорм інфрормації;

- мета складання управлінської звітності джерело інформації для контролю, аналізу, бюджетування та прийняття управлінських рішень.

На нашу думку, саме Куцик П.О. дав більш точне тлумачення стосовно внутрішньої та управлінської звітності назвавши ії внутрішньо-корпоративною управлінською звітністю, оскільки така звітність має для підприємства охоплювати весь спектр діяльності.

Для корпоративних об'єднань таке поняття звітності як «внутрішня звітність» або «управлінська звітність» $\epsilon$ недостатньо інфрормативним і показовим, тому доцільно використовувати термін «внутрішньо-корпоративна управлінська звітність». Такий термін розкриває в собі інорормацію про ціль подальшого використання викладеної у цій звітності інсрормації, а також і суб'єктів, чиїх інтересів вона торкається. А якщо розглядати кожну 3 категорій окремо «внутрішня звітність» та «управлінська звітність», то видно, що вони не повною мірою містять все змістове навантаження досліджуваного поняття. У свою чергу термін «внутрішньо-корпоративна управлінська звітність» вносить ясність у розуміння досліджуваного явища, оскільки передбачає розуміння цілей використання, суб'єктів інорормації, порядку складання такої звітності.

Виходячи з вищезазначеного, уявляється доцільним запропонувати власне тлумачення «внутрішньо-корпоративна управлінська звітність» - це система взаємопов'язаних показників які визначають фрінансові та інші (виробничі, технологічні тощо) результати діяльності корпоративного об'єднання в грошовому та натуральному вимірах, що ґрунтуються на відображенні поточних i передбачуваних явищ господарської діяльності корпоративного об'єднання загалом і в розрізі сегментів управлінського поділу (види діяльності; види продуктів виробництва; підприємства, що входять до його складу; центри відповідальності, для потреб управління тощо).

Якщо розглядати управлінську звітність як джерело інсрормації, слід звернути увагу на основні вимоги щодо інфоормації та ії основні критерії. Менеджери різних рівнів управління для прийняття управлінських рішень, використовують різну інсрормацію. Розглядаючи управлінську звітність як джерело інформації про стан підприємства, варто звернути увагу на основні вимоги щодо інформації, основні 
Таблиця 1

Трактування сутності поняття «внутрішня звітність» у працях науковців

\begin{tabular}{|c|c|}
\hline Автор [джерело] & Визначення сутності поняття \\
\hline 01 & 02 \\
\hline $\begin{array}{c}\text { Адамов } \mathrm{H} . \\
\text { [2] }\end{array}$ & $\begin{array}{l}\text { Управлінська звітність - це комплекс взаємопов'язаних даних } \\
\text { і розрахункових показників, які відображають функціонування } \\
\text { підприємства як суб'єкта господарської діяльності та згруповані загалом } \\
\text { по підприємству і в розрізі структурних підрозділів. }\end{array}$ \\
\hline $\begin{array}{c}\text { Бутинець Ф. Ф. } \\
\text { [4] }\end{array}$ & $\begin{array}{l}\text { Внутрішня бухгалтерська звітність - це комплекс взаємопов'язаних } \\
\text { даних і розрахункових показників, які відображають функціонування } \\
\text { підприємства як суб'єкта господарської діяльності та згруповані загалом } \\
\text { по підприємству і в розрізі структурних підрозділів. }\end{array}$ \\
\hline $\begin{array}{l}\text { Височан О. С., } \\
\text { Кіш I. P. } \\
\text { [5] }\end{array}$ & $\begin{array}{l}\text { Внутрішньогосподарська звітність є одним із основних джерел } \\
\text { надання інформації керівництву і дає можливість створювати } \\
\text { належну інформаційно-аналітичну базу для прийняття обґрунтованих } \\
\text { управлінських рішень на рівні підприємства, а також контролю за їхнім } \\
\text { виконанням по управлінській вертикалі }\end{array}$ \\
\hline $\begin{array}{l}\text { Карпенко О. В., } \\
\text { Любимов М. О. } \\
{[7]}\end{array}$ & $\begin{array}{l}\text { Управлінська звітність розглядається як система звітів у цілому } \\
\text { по підприємству і щодо окремих аспектів його діяльності з метою } \\
\text { забезпечення внутрішніх користувачів необхідною індрормацією для } \\
\text { обґрунтування управлінських рішень. }\end{array}$ \\
\hline $\begin{array}{c}\text { Колос I. В. } \\
{[8]}\end{array}$ & $\begin{array}{l}\text { Під управлінською звітністю потрібно розуміти звітність, яка складається } \\
\text { менеджерами різних рівнів управління і містить оцінку результатів } \\
\text { діяльності та прогнозні напрями її розвитку }\end{array}$ \\
\hline $\begin{array}{c}\text { Король С. Я. } \\
\text { [9] }\end{array}$ & $\begin{array}{l}\text { Управлінська звітність - це звітність для внутрішніх користувачів, } \\
\text { яка включає інформацію про господарську діяльність підприємства } \\
\text { та умови її здійснення, підготовлена з використанням методичних } \\
\text { прийомів бухгалтерського обліку, планування, аналізу, контролю й інших } \\
\text { дисциплін }\end{array}$ \\
\hline $\begin{array}{l}\text { Корягін М. В., } \\
\text { Куцик П. О. } \\
\text { [10] }\end{array}$ & $\begin{array}{l}\text { Внутрішня управлінська звітність - це інфрормаційний продукт, що є } \\
\text { набором відповідних облікових показників, який виступає основним } \\
\text { засобом інформаційної підтримки прийняття менеджментом } \\
\text { підприємства управлінських рішень. }\end{array}$ \\
\hline $\begin{array}{c}\text { Коноваліхіна Т.О. } \\
\text { [11] }\end{array}$ & $\begin{array}{l}\text { Управлінська звітність - система показників оцінювання результатів } \\
\text { бізнесу та перспектив його розвитку, що надається внутрішнім } \\
\text { користувачам для задоволення інформаційних потреб у процесі } \\
\text { прийняття стратегічних, тактичних і оперативних управлінських рішень. }\end{array}$ \\
\hline $\begin{array}{c}\text { Кузнецова С. А. } \\
{[12]}\end{array}$ & $\begin{array}{l}\text { Управлінська бухгалтерська звітність - це бухгалтерська звітність, що } \\
\text { містить облікову інформацію про діяльність підприємства та надається } \\
\text { внутрішнім користувачам у процесі управління підприємством. }\end{array}$ \\
\hline $\begin{array}{c}\text { Куцик П. О. } \\
\text { [13] }\end{array}$ & $\begin{array}{l}\text { Внутрішньо-корпоративна управлінська звітність - це система } \\
\text { взаємопов'язаних показників, що визначають фінансові та інші } \\
\text { (виробничі, технологічні тощо) результати діяльності корпоративного } \\
\text { об'єднання в грошовому та натуральному вимірах, що ґрунтуються на } \\
\text { відображенні поточних і передбачуваних явищ (подій) господарської } \\
\text { діяльності корпоративного об'єднання загалом і в розрізі сегментів } \\
\text { управлінського поділу (види діяльності; види продуктів виробництва; } \\
\text { підприємства, що входять до його складу; центри відповідальності, для } \\
\text { потреб управління тощо) }\end{array}$ \\
\hline $\begin{array}{c}\text { Нападовська Л. В. } \\
{[16]}\end{array}$ & $\begin{array}{l}\text { Управлінська звітність - це гнучка система фрорм інфрормації, яка } \\
\text { складається за центрами затрат і центрами відповідальності. Вона } \\
\text { повинна відображати умови, специфріку, особливості організації } \\
\text { виробництва та потреби управлінського персоналу }\end{array}$ \\
\hline
\end{tabular}


критерії, групи та інше. Залежно від управлінської ланки, якій подається інорормація, можна виділити такі основні 3 групи інфрормації $[18$, с. 7-8]:

1. Стратегічна інфрормація. Як правило, таку інсрормацію використовує вище керівництво. Дана група інсрормації охоплює широкий спектр проблем, вона характеризується зовнішньою спрямованістю, високим рівнем узагальнення та значним часовим діапазоном.

2. Тактична інсрормація. Така інформація призначена для керівників середньої ланки. Ця група інфрормації охоплює вужчий, ніж на стратегічному рівні, спектр проблем і має як зовнішню, так і внутрішню спрямованість. Вона характеризується низьким рівнем узагальнення і достатньо високим рівнем точності.

3. Оперативна інфрормація. Таку інфоормацію використовують керівники нижчого рівня управління. Така інформація охоплює дуже вузький спектр проблем, має внутрішню спрямованість, низький рівень узагальнення, дуже високий рівень точності.

Слід зазначити, що важливою характеристикою інфрормації на підприємстві $€$ коноріденційність, бо саме вона фрормується і може охоплювати як стратегічну, тактичну так і оперативну групи. В свою чергу, конфріденційність інформації полягає в тому що, для ефрективного управління підприємством, покращенням його фрінансових результатів, а також у зв'язку із зростанням конкуренції і навіть виникнення умов «виживання» підприємства, застосування будь-яких засобів, методів і прийняття рішень, які $є$ прийнятними, якщо вони звичайно не порушують норм законів.

Як вже зазначалося вище, внутрішньогосподарська звітність призначена для прийняття оперативних управлінських рішень, контролю, прогнозування та планування діяльності, а також для оцінки результатів виконаних рішень. Таким чином, слід складати таку звітність, яка б могла чітко показати стан всіх рівнів діяльності підприємства.

Як зазначив Марків М. М., оперативна звітність - це звітність, яка фрормується на основі обліково-аналітичної інорормації про досягнення цільових показників роботи центрів відповідальності, що дає змогу оцінити ефрективність фрункціонування підприємства у розрізі поставлених оперативних цілей [15].

Для оперативної звітності характерно те, що вона складається за допомогою даних оперативного обліку (системи спостереження та поточного контролю за окремими фрактами чи процесами 3 метою управління ними в момент їх здійснення) та містить інформацію про основні показники діяльності підприємства за короткі проміжки часу - добу, тиждень, декаду. Така звітність розробляється і затверджується на кожному підприємстві та характеризує окремі господарські операції. Вона має бути індивідуальною та диференційованою. Головним її завданням $€$ надання оперативної інорормації для прийняття своєчасних рішень за поточний період. Така інформація використовується для оперативного контролю та управління такими процесами, як постачання, виробництво та реалізація продукції і представляє собою внутрішні документи, що розробляються на підприємствах, характеризують окремі господарські операції. Основним її завданням $€$ надання оперативної інорормації для прийняття своєчасних управлінських рішень за визначений період.

Стосовно поняття «управлінські рішення» Фатхутдінов Р.А. зазначає: «результат аналізу, прогнозування, оптимізації, економічного обґрунтування й вибору альтернативи з безлічі досягнення конкретної мети системи». Проте це визначення претендує на визначення бажаного результату в рамках системи менеджменту. Не в усіх випадках особа, яка приймає рішення, або суб'єкт управління для одержання рішення буде вдаватися до методів прогнозування, оптимізації й економічного обґрунтування [19].

На нашу думку, особливості прийняття управлінських рішень залежать від рівня невизначеності досягнення бажаних результатів, передбачених кінцевою і проміжною метою управлінського процесу. Інорормація, яка буде використовуватись для прийняття управлінських рішень повинна насамперед враховувати основні етапи процесу прийняття таких рішень, а також відповідати певним основним вимогам.

Науковці у своїх працях визначають як критерії фрормування управлінської звітності, так і вимоги щодо інфрормації управлінської звітності (табл. 2).

Вище зазначені вимоги, на нашу думку, $є$ основними принципами оцінки системи показників управлінської звітності, оскільки вони можуть повністю розкрити стан роботи підприємства, а також надати важливу та достовірну інфрормацію для прийняття подальших управлінських рішень.

Висновки. Отже, внутрішня звітність являє собою основу для прийняття управлінських рішень на всіх рівнях керування організацією. Також вона $€$ основним джерелом інформації 
Вимоги до формування управлінської звітності

Таблиця 2

\begin{tabular}{|c|c|}
\hline Вимоги & Значення \\
\hline 01 & 02 \\
\hline суттєвість & $\begin{array}{l}\text { індрормація, відсутність якої може вплинути на управлінські } \\
\text { рішення; досяжність - мета, а не абстракція, результат досліджень } \\
\text { передбачень, початкових варіантів управлінських рішень }\end{array}$ \\
\hline своєчасність & $\begin{array}{l}\text { інфрормація, повинна випереджати будь-які управлінські рішення, а } \\
\text { тому порядок і частота такої інфоормації мають відповідати характеру } \\
\text { та періодичності завдань, що розв'язують менеджери }\end{array}$ \\
\hline адресність & $\begin{array}{l}\text { індрормація повинна відповідати потребам конкретного } \\
\text { користувача, відповідати рівню його підготовленості до сприйняття і } \\
\text { уповноваженням в ієрархії підприємства }\end{array}$ \\
\hline зрозумілість & $\begin{array}{l}\text { передбачає не тільки розкриття інформації, але і ії повноту, } \\
\text { достовірність та зрозумілість для користувачів яким вона подається }\end{array}$ \\
\hline повнота & $\begin{array}{l}\text { інфрормація є достатньою для розуміння ситуації та прийняття } \\
\text { правильних стратегічних і економічних рішень }\end{array}$ \\
\hline корисність & $\begin{array}{l}\text { інфрормація повинна привертати увагу користувачів до напрямів } \\
\text { потенційного ризику і давати можливість об'єктивно оцінювати } \\
\text { ситуацію }\end{array}$ \\
\hline варіативність & $\begin{array}{l}\text { інфрормація повинна забезпечувати можливість вибору варіанта } \\
\text { управлінського рішення з декількох взаємовиключних альтернатив }\end{array}$ \\
\hline економічність & $\begin{array}{l}\text { сукупність повідомлень, зміст яких необхідний на різних рівнях } \\
\text { планування та управління економічними об'єктами }\end{array}$ \\
\hline $\begin{array}{l}\text { доступність } \\
\text { фрорми і змісту }\end{array}$ & $\begin{array}{l}\text { оскільки інфрормація готується для менеджерів різних рівнів } \\
\text { компетенцій та освіти, вона повинна викладатися в доступній та } \\
\text { корисній формі, а не у вигляді регламентованих загальних документів } \\
\text { звітності }\end{array}$ \\
\hline достовірність & $\begin{array}{l}\text { властивість інформації відображати реально діючі або адекватні } \\
\text { дані про господарські явища, які визначені достовірністю результатів } \\
\text { аналізу }\end{array}$ \\
\hline дифреренційованість & $\begin{array}{l}\text { інформація має бути достатньо повною, але водночас такою, що } \\
\text { відповідала б тільки запиту менеджера на конкретне завдання. Це } \\
\text { дасть можливість скоротити загальні інформаційні потоки }\end{array}$ \\
\hline $\begin{array}{l}\text { релевантність } \\
\text { (відповідність) }\end{array}$ & $\begin{array}{l}\text { наявність зв'язку з проблемою і здатність інформації долучитися до } \\
\text { розуміння проблеми, тобто зіставити цю інформацію з інформаційними } \\
\text { потребами і відповісти на запитання, чи зможе допомогти вона вам } \\
\text { зараз або в найближчому майбутньому }\end{array}$ \\
\hline директивність & $\begin{array}{l}\text { інфрормація може містити дані або показники, які можуть мати } \\
\text { певні вказівки або рекомендації відповідно до внутрішніх норм та } \\
\text { розпоряджень }\end{array}$ \\
\hline субординація & $\begin{array}{l}\text { інфрормація сорормована у відповідності до правил службової } \\
\text { дисципліни, систематизована до певного підпорядкування на різних } \\
\text { рівнях управління }\end{array}$ \\
\hline компактність & $\begin{array}{l}\text { звітні фрорми мають бути максимально спрощені, але до меж, які } \\
\text { дозволятимуть контролювати не тільки підсумкові показники, а й їх } \\
\text { складові }\end{array}$ \\
\hline
\end{tabular}

Джерело: складено автором на основі джерела [1] 
про діяльність підприємства і важливим інструментом контролю за господарською діяльністю його підрозділів. Слід зазначити, що внутрішня управлінська звітність повинна бути: оперативною, короткою, корисною та подаватися тоді, коли вона необхідна для прийняття конкретних управлінських рішень та без зайвої інорормації, щоб можна було оперативно оцінити її зміст. Також вона повинна бути достовірною, об'єктивною і зрозумілою, щоб кожен конкретний відповідальний менеджер міг отримувати ту інфрормацію, у якій зацікавлений саме він.

Як показує практика, сьогодні фрункціонує багато великих підприємств, які складають та подають керівництву управлінську бухгалтерську звітність без загальних правил фрор- мування. Таке явище свідчить не тільки про відсутність регулювання на підприємстві, а й про недостатню кваліфрікацію працівників. Таким чином, щоб підприємство вело успішну господарську діяльність та надавало чітку та зрозумілу інформацію про стан підприємства для прийняття управлінських рішень, на наш погляд, необхідно розробити систему управлінської звітності, головною метою якої буде надання інформації стосовно: рівня прибутковості; рівня витрат; зіставлення показників за різні періоди та між фрактичним виконанням і плановим завданням. А також буде містити інформацію про наслідки раніше прийнятих рішень і буде слугувати інорормаційним джерелом для прийняття рішень на перспективу.

\section{СПИСОК ВИКОРИСТАНИХ ДЖЕРЕЛ:}

1. Національне положення (стандарт) бухгалтерського обліку 1 «Загальні вимоги до фрінансової звітності»: наказ від 28.02.2013 р. № 336/22868. URL: https://zakon.rada.gov.ua/laws/show/z0336-13\#Text

2. Адамов Г. Внутренняя управленческая отчетность: принципы, виды и методы составления. Финансовая газета. 2007. № 30.

3. Бакаев А.С. Толковый бухгалтерский словарь. 2006. 164 с.

4. Бутинець Ф.Ф. Бухгалтерський управлінський облік : підручник. Житомир, 2002. 480 с.

5. Височан О.С. Формування системи якісних критеріїв внутрішньогосподарської звітності для задоволення потреб керівництва підприємства. Економіка, фрінанси, право. 2014. Вип. 3-1. С. 3-7.

6. Данкевич А.Є. Методологічні основи розвитку бюджетування у сільському господарстві. Економіка АПК. 2008. № 6. С. 64-69.

7. Карпенко О.В. Класифікація управлінської звітності як основа розуміння її сутності. Наукові записки Національного університету «Острозька академія». Серія «Економіка». 2011. Вип. 16. С. 145-151.

8. Колос І.В. Звітність як елемент системи управління підприємством. Економіка та держава. 2006. № 8. С. 26-31.

9. Король С.Я. Управлінськазвітність: сутністьіалгоритм формування. Бізнес/нфрорм. 2014. № 7. С. 325-330.

10. Корягін М.В. Проблеми та перспективи розвитку бухгалтерської звітності : Монограсія. Київ, 2016. 276 с.

11. Коноваліхіна Т.О. Управлінська звітність в системі обліково-аналітичного забезпечення менеджменту ресторану. Обліково-аналітичне забезпечення системи менеджменту підприємства (м. Львів, 23-24 жовт. 2009 р.). 2009. C. 55-56.

12. Кузнецова С.А. Управлінська бухгалтерська звітність: проблеми створення. Бухгалтерський облік $і$ aydum. 2008. № 11. С. 15-24.

13. Куцик П.О. Сучасне трактування, склад і особливості формування управлінської звітності підприємства. Вісник Національного університету «Львівська політехніка». 2014. № 797. С. 248-254.

14. Ластовецький В.О. Виробничо-комерційний облік і внутрішньо-господарська (управлінська) звітність за центрами витрат і відповідальності. Чернівці, 2003. 156 с.

15. Марків М.М. Організація управлінського обліку на деревообробних підприємствах із виробництва твердого біопалива : дис. канд. екон. наук. Івано-Франківськ, 2016.

16. Нападовська Л.В. Управлінський облік : підручник. 2010. 648 с.

17.Палий В.Ф. Управленческий учет издержек и доходов с элементами фринансового учета. Москва : ИНФРА-М, 2006. 279 C.

18. Партин Г.О. Управлінський облік : підручник. Львів : Вид-во Львівської політехніки, 2013. 280 с.

19. Фатхутдинов Р.А. Разработка управленческого решения. ЗАО «Бизнес-школа «Интел-Синтез»», 1998. 272 с.

\section{REFERENCES:}

1. National accounting regulation (standard) 1 «General requirements for financial reporting» no. 336/22868 (2013, February 28). Retrieved from: https://zakon.rada.gov.ua/laws/show/z0336-13\#Text 
2. Adamov G. (2007) Vnytrinnyaya upravlencheskaya otchetnost: prinsipi, vidi I metodi sostavlenia [Internal management reporting: principles, types and methods of preparation]. Finansovaya gazeta [Financial newspaper], no. 30.

3. Bakaev A.S. (2006) Tolkoviy buhalterskiy slovar [Explanatory accounting dictionary], $164 \mathrm{p.}$

4. Butinets F.F. (2002) Buhalterskiy upravlinski oblik [Management accounting]: Textbook. Jitomir, $480 \mathrm{p}$.

5. Visochan O.S. (2014) Formuvannya sistemi yakisnih kriteriiv vnutrishnogospodarskoi zvitnosti dlya zadovolennya potreb kerivnictva pidpriemstva [Formation of a system of qualitative criteria for internal reporting to meet the needs of enterprise management]. Economica, finansi, pravo [Economics, finance, law], no. 3-1, pp. 3-7.

6. Dankevich A.E. (2008) Metodologichni osnovi rozvitky budjetuvannya u silskomu gospodarstvi [Methodological bases of budgeting development in agriculture]. Economica APK [Economics of agro-industrial complex], no. 6, pp. 64-69.

7. Karpenko O.V. (2011) Klasifikacia upravlinskoi zvitnosti yak osnova rozuminnya ii sutnosti [Classification of management reporting as a basis for understanding its essence]. Naukovi zapiski Nacionalnogo universitetu «Ostrozka academia». Series «Economy», no. 16, pp. 145-151.

8. Kolos I.V. (2006) Zvitnist yak element sistemi upravlinnya pidpriemstvom [Reporting as an element of the enterprise management system and the state]. Ekonomika ta derjava, no. 8, pp. 26-31.

9. Korol S.Y. (2014) Upravlinska zvitnist: sutnist I algoritm formuvannya [Management reporting: the essence and algorithm of formation]. Bussines/nform, no. 7, pp. 325-330.

10. Koryagin M.V. (2016) Problemi ta perspektivi rozvitku buhgalterskoi zvitnosti [Problems and prospects of financial reporting development]. Kyiv, $276 \mathrm{p}$.

11. Konovalihina T.O. (2009) Upravlinska zvitnist v sistemi oblikovo-analitichnogo zabezpechennya menedjmentu restoranu [Management reporting in the system of accounting and analytical support of restaurant management]. Oblikovo-analitichne zabezpechennya sistemi menedjmentu [Accounting and analytical support of the enterprise management system] (Lviv, October 23-24, 2009), pp. 55-56.

12. Kuznetsova S.A. (2008) Upravlinska buhgalterska zvitnist: problem stvorennya [Management accounting: problems of creation]. Buhgalterski oblik i audit [Accounting and auditing], no. 11, pp. 15-24.

13. Kutsik P.O. (2014) Suchasne traktuvannya, sklad i osoblivosti formuvannya upravlinskoi znitnosti pidpriemstva [Modern interpretation, composition and features of the formation of management reporting of the enterprise]. Visnik Natsionalnogo universitetu «Lvivska politehnika» [Bulletin of the National University «Lviv Polytechnic»], no. 797 , pp. 248-254.

14. Lastovetski V.O. (2003) Virobnicho-komertsiiniy oblik i vnutrishnogospodarska (upravlinska) zvitnist za tsenrami vitrat i vidpovidalnosti [Production and commercial accounting and internal economic (management) reporting by cost and responsibility centers]. Chernivtsi, $156 \mathrm{p}$.

15. Markiv M.M. (2016) Organizatsia upravlinskogo obliku na derevoobrobnih pidpriemstvah iz virobnitstva tverdogo paliva [Organization of management accounting at woodworking enterprises for the production of solid biofuels]. Candidate's thesis. Ivano-Frankivsk.

16. Napadovska L.V. (2010) Upravlinski oblik [Managerial Accounting]: textbook, 648 p.

17. Paliy V.F. (2006) Upravlencheskiy uchet izderzhek I dohodov s elementami finansovogo ucheta [Management accounting of costs and revenues with elements of financial accounting]. Moskva: INFRA-M, $279 \mathrm{p}$.

18. Partin G.O. (2013) Upravlinskiy oblik [Managerial Accounting]: textbook. Lviv: Lviv Polytechnic Publishing House, $280 \mathrm{p}$.

19. Radhutdinov R.A. (1998) Razrabotka upravlencheskogo reshenia [Development of a management decision]. CJSC ««Intel-Synthesis» Business School», 272 p. 